\title{
CHANGE OF SOVEREIGNTY OF A PEOPLE AND THE UNITED STATES CONSTITUTION.
}

History does not furnish us with a well defined precedent where a nation, in case of conquest or acquisition of foreign territory, has ever succeeded in abolishing the laws and customs of a people brought under its dominion.

Pilate surrendered Christ to the Sanhedrim because $\mathrm{He}$ had offended only against the Jewish authorities. Upon the overthrow of the Roman Empire by the Northern barbarians, Theoderic, the enlightened king of the Ostrogoths, proclaimed: "that other kings had made their conquests at the ruination of the conquered peoples; that he, on the contrary, only desired that the Romans might congratulate themselves on the benefits of his dominion." His government was marked by a few radical changes in existing institutions and by that humane and considerate policy which was observed by the Visigoths upon their entrance in Spain, in permitting the inhabitants to continue in the exercise of their own laws and customs while the conquerors practiced the unwritten laws and observances of the Goths. ${ }^{1}$ William the Conqueror upon his invasion of the British Isles was not able to extinguish Anglo-Saxon ideas of rights and justice; and the Moors occupied the Iberian Peninsula nearly eight centuries and, although their sway affected legislation, ${ }^{2}$ they left it Spanish. Warren Hasting's Plan of 1772 for the government of British India continued Mohammedan Law in force; Austria has seen good reasons for not attempting to make changes in Hungary; while it is surprising to find how Spanish everything is even to-day throughout LatinAmerica.

And so it would seem that upon the broad and general grounds "of the eternal fitness of things," aside from the political and legal aspects of the case, the United States of

${ }^{1}$ Walton's Civil Law in Spain and Spanish-America, pp. 39-43.

${ }^{2}$ Walton's Civil Law in Spain and Spanișh-America, p. 63. 580 
America should not ex abrupto force its Constitution as a whole with its far reaching results, nice distinctions and discriminations, many of which are peculiar to the common law, upon a civil law people who are strangers to Anglo-Saxon legislation and customs and who will require at least a generation in which to understand and to be able to differentiate the two systems.

The maintenance and extension of our national dominion is a political and not a judicial problem, notwithstanding the existing evil, if evil it be, of too much judge-made law. The President and Congress are vested with all the responsibility and powers of the government for the determination of questions as to the maintenance and extension of our national dominion. It is not the province of the courts to participate in the discussion or decision of these questions, for they are of a political nature and not judicial. Congress and the President having assumed jurisdiction and sovereignty - . all the people and the courts of the country are bound by such governmental acts. ${ }^{3}$

Questions also incident to acquisition and preliminary to government, whether the territory be contiguous or remote, whether our tenure be temporary or permanent, whether we keep, lease, sell or grant independence; these are all political matters intrusted without appeal to the discretion of Congress. ${ }^{4}$ The act transferring a country from one sovereignty to a new one transfers the allegiance of its inhabitants. They, however, do not participate in political powers, nor can they share in the powers of the (new) general government, until they become a state. ${ }^{5}$

It is a well recognized principle of international law that the cession of sovereignty over a country by one nation to another affects only the political relations of the inhabitants of the ceded country, and makes them subjects thereafter of the nation receiving the cession; that while the inhabitants of the ceded territory change their allegiance, their relations to each other and their rights of property remain undis-

so Fed. Rep. Iro.

${ }^{4}$ I4 Pet. 538; 9 How. 242; I8 Wall. 320 ; 10I U. S. I33.

story on the Const., Sec. I234; I Pet. 542; Halleck's Int. Law, p. 380 (Baker's ed.) ; 2 Whart. Dig. Int. Law, p. 425 . 
turbed. ${ }^{6}$ Laws, usages and municipal regulations in force at the time of cession remain in force until changed by the new sovereignty. The new sovereign may deal with the inhabitants and give them what law it pleases, unless restrained by the treaty of cession but until alteration be made, the former law continues. ${ }^{7}$

By the recent treaty with Spain sovereignty is ceded to the United States over Puerto Rico and the Philippine Islands with the following proviso: "The civil and political status of the native inhabitants of the territories hereby ceded to the United States shall be determined by Congress." The ceding power imposes no conditions and reserves no rights defined and secured by the Federal Constitution to the inhabitants of these new possessions.

None of our territories have ever been organized under the Constitution but are creatures exclusively of the legislative department of the government and subject to its supervision and control, ${ }^{8}$ and in a territory all the functions of government are within the legislative jurisdiction of Congress; $;$ consequently, it is for Congress to decide what the political status of residents of our new possessions shall be; whether they shall exercise the rights of suffrage or not, and that right, if granted, may be limited or extended at the will of Congress.

The late treaty with Spain is distinguished from all others heretofore made by the United States in the acquisition of new territory. It is provided in the treaty of 1803 for the cession of Louisiana that: "The inhabitants of the ceded territory shall be incorporated in the Union of the United States, and admitted as soon as possible, according to the principles of the Federal Constitution, to the enjoyment of all the rights, advantages, and immunities of the citizens of the United States; and in the meantime they shall be maintained and protected in the free enjoyment of their liberty, property, and the religion which they profess."

'Vattel, Book 3, Chap. I3; I Pet. 5II; 7 Pet. 5I; 9 Pet. 7II; I2 Pet. 4IO.

'9 Pet. 7II; I6 How. I64.

9 How. 242.

๑86 Fed. Rep. 459. 
The treaty of I8Ig by which Florida was ceded to the United States contains a similar provision in Article VII. The administration of Mr. Monroe, expressly, by unanimous cabinet decision, and each House of Congress, impliedly and without division, decided that no part of the Constitution and no act of Congress applied to a territory unless extended to it by Congress. The question arose by Judge Fromentin issuing a writ of habcas corpus to have the body of exGovernor Callava (then imprisoned by the order of General Jackson) brought before him, claiming the right to do so under the Constitution and under the laws of Congress vesting United States judges with that power. Governor Jackson denied the power and dealt militarily with the judge for issuing the writ, telling him that no part of the Constitution had been extended to the Floridas, nor any act of Congress authorized him to issue the writ. The case was brought before the President and Congress with the above stated result. ${ }^{10}$

The act for the temporary government of Florida was not an isolated instance in the history of our territorial legislation: it but copied in almost the exact words the first act for the establishment of a temporary government in Louisiana. The "liberty, property and religion," the free enjoyment of which was guaranteed to the inhabitants of the territories by these acts, were subject to the despotic authority exercised by the American Governor, as the successor of the Spanish captain-general, and this despotic government in Florida actually lasted four years. Senator Benton states that: "Two different administrations and two different Congresses, at the distance of sixteen years apart, governed two acquisitions of new territory exactly alike, and as incompatibly with our Constitution as a Spanish regal despotism is incompatible with our free republican government."

The treaties by which New Mexico, Utah. California were acquired in 1848 and 1853 , embrace provisions similar to the Florida treaty (Articles VIII, IX, and V).

The treaty of 1867 by which Alaska was acquired has no provision for the incorporation of the Territory into the

\footnotetext{
1" Benton's Examination of the Dred Scott Case, pp. 4, 73.
} 
Union as a state or states. It clivides the inhabitants into two classes, and provides that they may return to Russia within three years, and in respect to those who do not return states: "But if they should prefer to remain in the ceded territory, they, with the exception of the uncivilized native tribes, shall be admitted to the enjoyment of all the rights, advantages, and immunities of citizens of the United States and shall be maintained and protected in the free enjoyment of their liberty, property, and religion. The uncivilized tribes shall be subject to such regulations as the United States may, from time to time, adopt in regard to aboriginal tribes of that country."

The Constitution and Federal laws have not been made operative in Alaska, and only such statutes have been extended to it as circumstances warranted. It is an organized territory, governed directly from Washington. Physically it is foreign, its nearest point being 400 , and its farthest 2,400 miles from Seattle. The Aleutian Islands extend even into the geographical limits of another continent. For thirty-two years a few judicial and executive, but no legislative. functions of government have been conferred upon the inhabitants. It is unquestionably within the constitutional power of Congress to withhold from the inhabitants of Alaska the power to legislate and make laws. ${ }^{11}$

In every treaty by which the United States has acquired inhabited territory, prior to the Paris treaty with Spain, the ceding power has inserted a provision that the inhabitants, except uncivilized tribes. shall be admitted to the enjoyment of all the rights, advantages, and immunities of citizens of the United States, and all, except that by which Alaska was acquired, contain the further provision that they shall in due time, to be determined by Congress, be admitted as a state or states into the Union. In the absence of treaty provisions, it, therefore, appears that the Constitution, with the exception of the Thirteenth Amendment, does not $c \boldsymbol{x}$ proprio vigore extend itself over the newly acquired territories.

Colonies are territories settled by citizens of the sovereign

${ }^{11}$ U. S. Rev. Stat., Sec. 1954; 29 Fed. Rep. .205. 
or parent state who left their native land to people another and to remain subject to the mother country. Puerto Rico and the Philippines already densely populated afford little opportunities for American colonization, and, therefore, can hardly be designated as colonies. Unorganized territories, such as Alaska and the Indian Territory, as we have seen, possess no local government and are not usually subject to the Constitution and Federal laws but are ruled directly by Congress. Organized territories, such as New Mexico and Arizona, are portions of the national domain over which Congress has extended the Constitution and Federal laws and in which a local government has been allowed to be established. ${ }^{12}$ Territories may be considered as either organized or unorganized dependencies or provinces, these words being in reality synonymous terms. The word "colony" has no place in the history of our government.

It is natural for the people of the United States to turn to the Federal Constitution, the bulwark of their rights and liberties, for the solution of all kinds of governmental problems, and in so doing there is a tendency to overlook one of its principal objects and purposes, namely: To provide means for the better distribution, exercise, and regulation of a greater part of the sovereign pozver of the United States than had existed under the Articles of Confederation. From the recognition of the independence of the United States among nations, from 1783 until 1787 , and until the time of its adoption, this government existed, however, and exercised sovereign power without the Constitution. Since its adoption and up to the present time, the government, in numerous cases, has exercised sovereignty independently of the Federal Constitution.

Clifford S. Walton, Licentiate in Civil Law.

Washington, D.C.

${ }^{12}$ U. S. Rev. Stat, Secs. 1839-95. 